\title{
On the hydrate of cadmium
}

\section{M.J. Nicklès}

To cite this article: M.J. Nicklès (1848) On the hydrate of cadmium, Philosophical Magazine Series 3, 32:215, 317-317, DOI: 10.1080/14786444808645989

To link to this article: http://dx.doi.org/10.1080/14786444808645989

册 Published online: 30 Apr 2009.

Submit your article to this journal 정

Џll Article views: 2

Q View related articles $₫$ 
The zinc has then been replaced by copper. If this ammoniacal solution of copper be agitated with zinc, this metal, conformably to its greater affinity for oxygen, will in its turn displace the copper, and it is precipitated upon the zinc in a very fine powder, and in a short time the liquor ceases to be blackened by sulphuretted hydrogen.

This, then, furnishes an example of reciprocal affinity which is worthy of attention, and from which chemical analysis may derive utility.-Ann. de Ch. et de Phys., Janvier 1848.

\section{ON THE HYDRATE OF CADMIUM. BY M. J. NICKLÈS.}

This hydrate may be obtained, like that of zinc, by means of am. monia, iron and cadmium, or by causing copper to act upon an ammoniacal solution of oxide of cadmium.

It is but slightly permanent, and is partially decomposed in the liquid in which it is formed. It would seem that this ready decomposition is owing to the energy of the reaction; at any rate the author has obtained it perfectly homogeneous, operating slowly by putting a strip of cadmium in communication with a bar of hardened iron, and immersing the whole in a $U$-shaped tube full of ammonia.

By allowing the ammoniacal mother-waters to stand, a fresh quantity of hydrate is deposited. If the surface of evaporation is great, it is deposited in tlocculi; if, on the contrary, the evaporation takes place in an imperfectly corked bottle, it is formed in mammillated masses, with traces of crystallization; and this is the form in which the author has usually obtained it.

M. Nicklès had only a small portion of this substance for analysis. It yielded-

$$
\begin{array}{ll}
\text { Oxide of cadmium.... } & 89 \cdot 74 \\
\text { Water } \ldots \ldots \ldots \ldots & \frac{10 \cdot 26}{100 \cdot 00}
\end{array}
$$

Calculation requires 87.63 of oxide and 12.37 of water; the substance had therefore evidently undergone some change previous to analysis. - Ilid.

\section{ACTION OF ACIDS AND ALKALIES ON ASPARAGIN AND ASPARTIC ACID. BY M. PIRIA.}

The author obierves, that all chemists who have examined asparagin have observed the great tendency which it possesses to be de. composed by acids and alkalies, yielding ammonia and aspartic acid. M. Liebig states, even aspartic acid, when boiled in strong hydrochloric acid or fused with potash, is converted into ammonia and a new acid. M. Piria has arrived at a very different conclusion; he finding that neither hydrochloric nor sulphuric acid sensibly acts on aspartic acid, nor is any effect produced by nitric acid when free from nitrous vapour. Asparagin, on the other hand, is decomposed by various acids at a boiling heat, yielding ammonia, which combines with the acid employed, and free aspartic acid.

M. Piria found that crystallized asparagin, boiled for about an 